\title{
THE INTERNATIONAL UNION FOR THE PROTECTION OF NATURE
}

TECHNICAL MEETING, THE HAGUE

19'H-22ND SEPTEMBER, 1951

Report by Valerie Boyle

On 19th September there assembled at The Hague some 130 people of many nationalities with a common interest in problems of nature protection. Through the courtesy of the Netherlands authorities the meeting was held in the Rolzaal, an upper chamber of the fine old thirteenth century Ridderzaal, or Knights' Hall, in the centre of the Binnenhof.

On the evening of 19 th a reception was given by IIis Excellency the Minister of Education, $\Lambda$ rts, and Sciences, and His Excellency the Minister of Agriculture, Fisheries, and Food.

On 20th September the session was opened by M. Ch. J. Bernard, President of the Union. In his speech of welcome M. Bernard stressed that this was not to be a conference but an informal working meeting to which people would come as experts, not delegates, and would meet as groups of friends. He then proposed that I.U.P.N. should withdraw and a different chairman be appointed for each day, and that M. van der Goes van Naters should become chairman of the conference.

M. van der Goes spoke under three headings-conservation by such means as laws and reserves; prescrvation of species; reconstruction and construction of landscape. The latter is of paramount importance in the Netherlands as exemplified by the polders, consisting of land reclaimed from the former Zuyder Zee. Here new landscapes are based on soil mapping and planning. Reconstruction has taken place on Walcheren, flooded during the war and replamned after its reclamation.

The first day's discussions followed the theme "Rural landscape as a habitat for flora and fauna in densely populated countries". Mr. E. M. Nicholson, on being appointed chairman for the day, urged speakers not to follow the example of the skylark. 'This bird, which has the longest period of song among our birds, rises trilling in ever widening circles, intoxicated by its own eloquence, and only comes down to earth when its song is finished, and then precisely where it started. Rather should they try to emulate the domestic hen, which only utters after it has laid an egg and then tells everyone exactly where to find it. Mr. Nicholson thought that the idea of making a plan 
to deal with an inundated area, as had been done in the case of Walcheren, could well be applied to other kinds of flood, both human and industrial.

M. Faegri, of the Botanical Museum, Bergen, sought to dispel

The Netilerlands

Approximate Scale 23 miles $=1$ inch

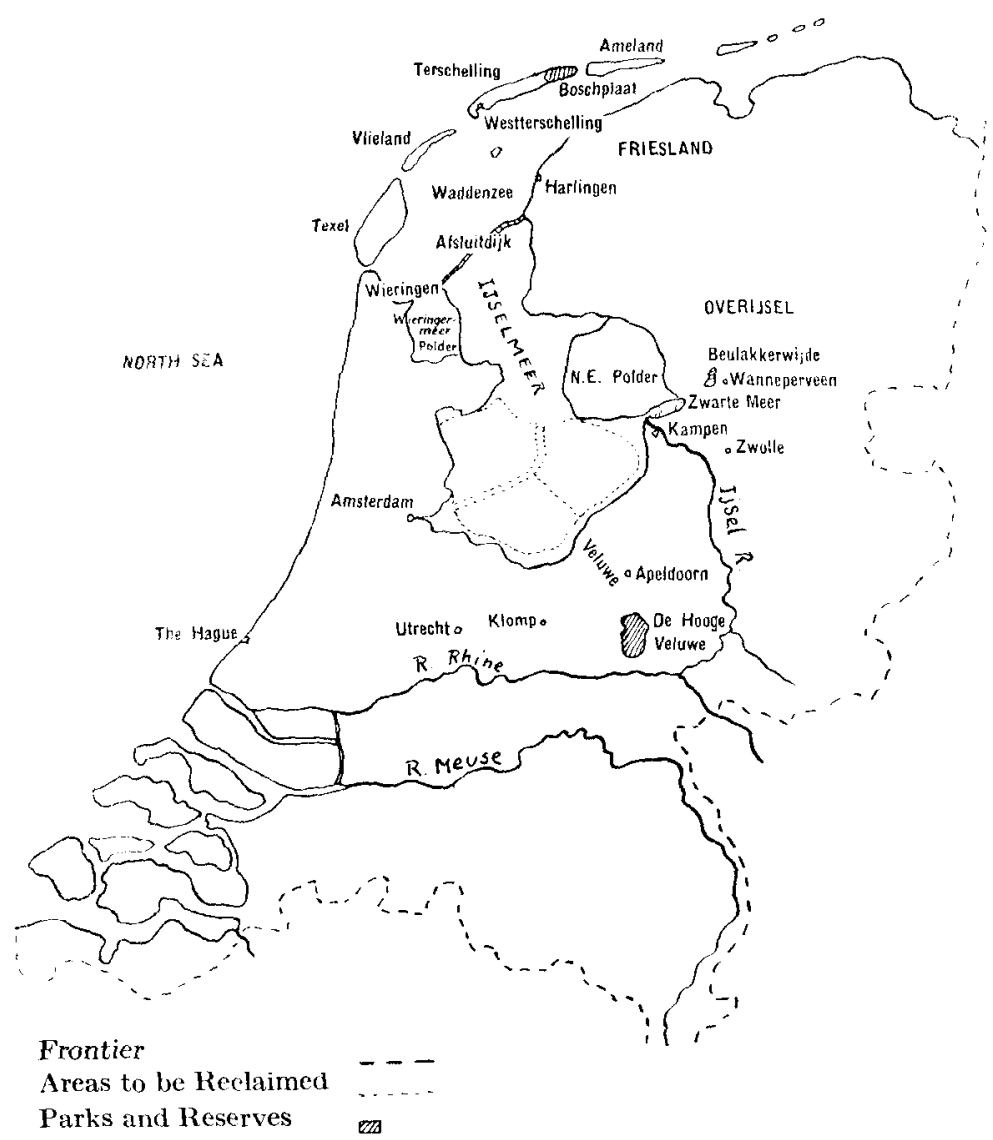

the phantom of "the natural landscape". Most of the so-called natural laws are, he said, laws of man imposed on nature. Since the introduction of agriculture by Neolithic Man there have been three variants acting upon the natural scene-soil, climate, and man. Their relative influence varied from place to place, and the aim should be a compromise between the three. 
All agreed on the necessity for rescarch and the wider exchange of information. The Union could act usefully as a central body which would put people in touch with those who had experience of similar problems in other countries. Mr. Jensen, of the British Nature Conservancy, described the function of that organization and mentioned some of the urgent problems requiring an ecological approach in Britain, such as coast protection and the recolonization of waste dumps. Many speakers showed what could be achieved by the co-operation of enginecrs and others working on development schemes. Mr. Berry, of the Nature Conservancy (Scotland) told how a scheme for a catchment aqueduct on Ben Lawers had been modified to save some valuable botanical specimens. Lord Hurcomb described how some of the reservoirs around London had become a haven for ground-nesting birds since the mowing of herbage on the banks and causeways had been prohibited.

M. Bernard spoke on the serious and far-reaching clfect of large-scale hydro-clectric projects in Europe and drew attention to the damage caused by changes in water levels and river courses.

It was then requested that the Executive Board of I.U.P.N. should seek an agreement between the Italian and Swiss Governments to prevent the building of a funicular railway to the summit of the Matterhorn.

The problem of edueation was also discussed. M. Bouillenne suggested that education of adults was of first importance as they have the power to influence youth. It was agreed that some instruction in nature protection could with advantage be given to engineers, many of whom werc willing to co-operate but did not know how to do so.

The chairman for the second day was M. Bouillenne, of the Botanical Institute of the University of Liège, the theme being "The Management of Nature Reserves". Discussion ranged around the necessity for proper legal safeguards in drawing up national park legislation. Mr. Nicholson said that where development was intended early information was essential so that the plan could be influenced and a battle avoided. Colonel Boylc described the work done by the Warden of the Kruger National Park, Colonel Sandenbergh, in providing boreholes to increase the park's water supply. It was agreed that around nature reserves protective zones should be established in which agriculture and hunting would be allowed, in so far as these do not oppose the scientific aims of the reserve.

On Saturday, 22nd, M. Bernard resumed the chair. 
Discussions took place under the headings of zoological gardens, wild animal trade and transportation, and possible intervention on behalf of the whale. M. Sunicr considered that the only excuse for zoos in the future would be for education and scientific rescarch. Several speakers stressed the need for keeping rare species, such as the grcat apes, out of the hands of animal dealers. The import of protected animals should be prevented unless it was certain that they were legally exported and were destined for scientific institutions and not for dealers. M. IIarroy said that the Union had come to an agrecment with the International Union of Zoo Directors, membership of which is carcfully controlled, and this body does exercise some control in the matter of which zoos should receive rare animals.

Speaking on the question of the whale, M. van Tienhoven was not optimistic about the general position. Italy, Japan, Argentine, and the Netherlands, he said, are all building whalcrs and encouraging increased catches, and the Blue Whale is rapidly disappearing. M. Bezemer pointed out that the permitted annual catch of $\mathbf{1 6 , 0 0 0}$ Blue Whale Units represented about double that number of whales of all species killed. M. Dahlbeck, from Stockholm, said that if extinction was to be avoided the annual figure of 16,000 should be cut to 10,000 units at once. The whale is protected internationally by rules compiled by the International Whaling Commission, and some speakers thought it would be a mistake for I.U.P.N. to interfere. It was generally agreed, however, that the Union should get into closer touch with the Whaling Commission with the object of getting information and making suggestions. Efforts should also be made to influence countries who are not yet members of the Commission.

The meeting ended with votes of thanks to the chairmen of the discussions and to the Dutch organizing committee headed by M. Bloemers, for their excellent arrangements.

Many of those who attended The Hague mecting took part in a four-day excursion, most ably organized by the Dutch committee, and designed to show some of the work being done for nature protection throughout the country. We left The Hague by motor coach at midday on Saturday and drove castwards by Utrecht and Klomp. South-east of the former Zuyder Zee we passed through the Veluwe, a comparatively old landscape of heath and woodlands, mostly protected either by the Government or by individual societies. Here also we passed the National Park "de Hooge Veluwe" of 16,500 acres, where there are interesting birds and some introduced mammals. Our 
road turned northwards through Apeldoorn to Kampen, in old borough near the mouth of the Ijsel River.

In the evening we drove through the southern part of the North-East Polder. The word "polder" denotes an area where the water level is under control. This particular polder, of some $\mathbf{1 2 0 , 0 0 0}$ acres, was the second area to be reclaimed from the former Zuyder Zee, now called the Ijselmecr, after the completion of the great dam in 1932. To make the land suitable for cultivation the polder was first drained by digging canals and ditches within the enclosing dyke. Then the State took over the working of the land for a period until the soil had lost its excess of salt; after this the land was leased to private farmers. The North-East Polder now presents a neat if rather regimented appearance with its parallel roads bordered with poplars. Groups of farm buildings are evenly spaced and surrounded by rectangles of trees. Flat ficlds are parcelled out in sizes suited to modem agriculture. Plans exist for the reclamation of three more polders which will help to provide land for the growing population of the Netherlands.

Later on we cruised in a launch on the eastern end of the Zwarte Meer, the Black Lake, once part of the Zuyder Zee and now a reserve for aquatic birds. Large flocks of pochard, including some red-crested pochard, mallard and pintail rose as we approached. Far away on a post in the reed beds sat an osprey.

We spent that night at Zwolle and enjoyed an excellent dinner generously provided by the Royal Dutch 'Touring Club. Dr. Herbert Smith, as a Vice-President of I.U.P.N., proposed the toast of the Queen of the Netherlands.

On Sunday we drove through the north-west part of the province of Overijscl, formerly one of the largest peat bogs of western Europe, but now reclaimed for agriculture. It is a picturesque countryside where the canals and tow-paths provide almost the only means of communication. Some families live in barges trading along the waterways; others in hamlets where the canal takes the place of the village street and the gardens are brilliant with dahlias. We were taken along some of the canals by motor punt from Wanneperveen and out on the Lake of Beulakkerwijde. Two marsh harricrs soared over the recd beds but otherwise few birds were to be seen.

From Harlingen, on the Friesland coast, we sailed for Terschelling in a small steamer, threading our way between the shallows and sandbanks of the Waddenzee. During the two hours crossing we saw a few seals pecring up inquiringly 
from the water, and many cormorants; on a sand spit off Vlieland were two parties of eider duck.

Terschelling Island is about 19 miles long by 6 miles broad and has about 3,000 inhabitants, largely farmers and retired sailors. The island consists roughly of dunes along the north side, a polder to the south, and a sand flat at each end. As we entered the harbour of Westterschelling, the principal town and only port, oystercatchers streamed across and turnstones ran along the breakwaters. The lighthouse, a great square tower rising up in the middle of the town, is equipped with perches for birds, and the top is floodlit.

Our first expedition on the island was to a part of the dune land, where we were shown examples of young, moving dunes and older static ones with progressive vegetation. 'Typical of the ecological studies that are being carried on throughuut the Netherlands is an experiment here in progress. Forestry operations in the past have drained away the water from this dune area and a small lake is now being made in the hope that the lost vegetation will reappear.

Monday was spent in a visit to the Boschplaat Reserve, the sand flat area at the east end of the island covering about 17 squarc miles. The whole party travelled picturesquely in horse-drawn covered wagons and passed a very pleasant and interesting day. Along the northern coast efforts have been made to build up the dunes by laying mats of dead reeds to collect the blowing sand, and then planting marram to hold it. Thickets of sea buckthorn, bright with orange berries, fringed the foot of these dumes. On a mud flat were standing some grey lag geese. Towards evening, from the shelter of the dyke enclosing the polder, we watched duck and waders at the sea's edge. Wigeon were in the majority, but among them werc pintail, teal and a few mallard. Oystercatchers, grey plover and curlew stood on the shore, while flocks of golden plover and lapwing wheeled over the inshore fields. Especially interesting were the large flights of greenshank passing over.

The return journey from Harlingen to The Hague was made via the Afsluitdijk, the great dam across the Ijselmeer built between 1927 and 1932 . It is a most impressive structure, about 20 miles long, 300 feet wide at water level, and 100 feet at the top. The water level in the Ijsclmeer is kept at about 16 inches below mean sea level in winter and somewhat higher in summer. This water is now practically fresh, becoming so surprisingly soon after its enclosure. The salt water fish died, their place being taken by freshwater species. Seals, cut off from the sea, 
escaped over the dyke. At the south-western end of the dam is the former island of Wieringen and the Wieringermeer Polder of about 50,000 acres. This polder was reclaimed in 1930 but was flooded again in 1945 by the Germans. Immediately after the armistice the breach in the dyke was closed and pumping was started. Now, six years later, the land and buildings are restored and prosperous, a tribute to the determination and hard work of the Dutch people.

\section{REVIEWS}

Two reference books on nature protection. Edited and published by the International Union for the Protection of Nature, 42 Rue Montoyer, Brussels :-

Procemdings and Papers of timf International, Technical, Conference on the Protection of Nature, Lake: Success, August, 1949. 195 Belgian francs, post free.

The Position of Nature Protection throvghout time World IN 1950. 220 Belgian francs, post free.

Neither of these books lends itself easily to review. The title of the first sounds fearsome but the book contains a most valuable collection of essays on nature conservation. For example :-

"Let's Teach Water Conservation," by O. E. Fink, Secretary, Friends of the Land, Columbus, U.S.A.

"Antrycide and African Game," by Captain Keith Caldwell, late Game Warden, Uganda, and Assistant Game Warden, Kenya.

"The Great Indian Rhinoceros in Assam," by Salim Ali, Honorary Secretary, Bombay Natural IIistory Society.

"World Wide Education of the Public in the Protection of Nature," by Iolo Williams.

The second book consists of reports from seventy countries on the state of nature preservation within their boundaries. Most of these reports are received from Nature Protection Societies, and being the result of a questionnaire sent out from I.U.P.N. they are conveniently similar in presentation. Soil, water, flora, fauna, minerals, reserves, education, and other matters being dealt with in turn.

There are some noticeable omissions, principally from Fast and Central Africa, but that is not the fault of the editors. 